\title{
Violent attacks against persons with albinism in South Africa: A human rights perspective
}

\author{
Maureen Mswela* \\ Senior Lecturer, Department of Jurisprudence, College of Law, University of \\ South Africa
}

\begin{abstract}
Summary
South Africans living with albinism are among the most marginalised and vulnerable of the country's citizens, yet very little attention is given to protecting them from human rights violations, threats and violent crime. Although the extent of violent crimes targeting South Africans with this condition has not reached the levels encountered in other African countries, new evidence indicates a surge in violent crimes against persons with albinism. The vulnerability of these persons requires immediate attention before it spirals out of control. It is clear that a case is to be made for compelling, in particular, the state to intervene. Based on the groundbreaking decision of the South African Constitutional Court in the Carmichele case, this article begins a debate on the state's affirmative duty to prevent, investigate and punish violent acts against persons with albinism, as it is feared that the incidents reported in South Africa may trigger copycat crimes. Provisions from international and regional human rights instruments relevant to the issues faced by persons with albinism highlighted in the article are explored briefly.
\end{abstract}

Key words: albinism; genetics; brutal killings; popular culture; cultural beliefs; stereotypes; right to life; right to dignity; right to freedom and security of the person

LLB (Pretoria) LLM (South Africa) LLD (South Africa); mswelmm@unisa.ac.za. The basis of this contribution stems from the author's doctoral thesis entitled 'A selection of legal issues relating to persons living with albinism'. The contribution was also presented at Harvard Medical School in the USA during the International Conference for Academic Disciplines, 26-30 May 2014. 


\section{Introduction and contextual background}

On 25 September 2015, two 19 year-old men pleaded guilty in the Vryheid Regional Court to the murder of Thandazile Mpunzi, a 20 year-old woman with albinism, and each was sentenced to 20 years' imprisonment. ${ }^{1}$ Mpunzi's mutilated and skinned remains were found in a shallow grave after the suspects had confessed and led the police to the site. 2 The National Prosecuting Authority recorded that the 17 year-old boyfriend of the deceased had her murdered so that he and his friends could use her body parts for muti. ${ }^{3}$ The Court heard that traditional healer Bhekukufa Gumede had told the deceased's boyfriend that 'muti mixed with the body parts of a person with albinism would make them rich'. ${ }^{4}$ On the basis of this the accused concocted a plot to kill Thandazile Mpunzi to obtain her body parts. ${ }^{5}$ On the afternoon of 1 August 2015, Mpunzi's boyfriend lured her to a remote area in the Phelandaba area of Emanguzi in Northern KwaZulu-Natal, where Mabuza and Khumalo attacked and strangled her before taking her body to a nearby forest. ${ }^{6}$ The assailants met the following day, mutilated the deceased's body and left with certain body parts. ${ }^{7}$ They later buried the remains of the body in another forest. 8

Thandazile Mpunzi was a victim of violent attacks and killing of persons with albinism for ritual purposes. Based on the belief that the body parts of persons with albinism have extraordinary powers, unscrupulous dealers have resorted to harvesting their body parts with the expectation that these can be used to help them become rich. ${ }^{9}$ The body parts are allegedly used as ingredients in rituals, concoctions and potions on the basis of the claim that their magic will bring prosperity to the user. ${ }^{10}$

1 ECR News Watch 'KZN murder: Two suspects plead guilty' https://www.ecr.co.za/ news-sport/news/kzn-albino-murder-2-suspects-plead-guilty/ (accessed 10 January 2017).

2 TIMES Live 'Commissioner outraged with the murder of albino woman' http:// www.timeslive.co.za/local/2015/08/22/Commission-outraged-at-killing-of-albinowoman (accessed 10 November 2015).

3 IOL Crime \& Courts 'Boyfriend jailed for albino muti murder' http://www.iol. co.za/news/crime-courts/boyfriend-jailed-for-albino-muti-murder-1990611 (accessed 10 January 2017).

4 As above.

5 As above.

6 As above.

7 As above.

8 As above.

9 CNN http://www.cnn.com/2009/WORLD/africa/11/29/tanzania.personswithalbi nism/index.html (accessed 5 January 2017).

10 J Schühle 'Medicine murder of people with albinism in Tanzania - How casino capitalism creates rumourscapes and occult economies' (2013) 2 Centre for Area Studies Paper Series 18. Also see SM Uromi 'Violence against persons with albinism and older women: Tackling witchcraft accusations in Tanzania' (2014) 2 International Journal of Education and Research 323 328; I Nzangi 'Securing the 
At the same time, persons with albinism have been ostracised and even murdered for exactly the converse reason, namely, because they are considered a curse and to bring bad luck on a community. ${ }^{11}$ Underlying all these perceptions is the failure to see albinism for what it is: a medical condition, ${ }^{12}$ one of an incredibly rare group of diseases, presenting as pigmentation variance in the skin, hair and/or eyes, owing to hereditarily-blocked melanin synthesis. ${ }^{13}$

In another alarming case as recently as 28 June 2016, a four yearold boy with albinism was reportedly kidnapped in Empangeni, KwaZulu-Natal. ${ }^{14}$ The incident sparked an uproar as the community expressed their anger over the alleged kidnapping. ${ }^{15}$ During the investigation leading to an arrest, police followed up information received about a woman who was purportedly arranging to sell a child with albinism for R100 000 to a well-known community member who is also a traditional healer in Emanguzi. ${ }^{16}$ The 28 year-old woman was apprehended by police and the child was reunited with his family.

The body parts of persons with albinism are believed to sell for enormous sums of money, and the fact that trading in albino body parts constitutes such a lucrative enterprise and a way to make quick money is an incentive for inhuman acts such as these.

Although the extent of violent crimes targeting South Africans with albinism has not reached the levels encountered in other African countries, an increase has in recent times been observed, the abovementioned cases being but two examples. In South Africa, attacks often go unreported and undocumented due to the code of silence

rights of people with albinism in Tanzania mainland: The fight against social exclusion' unpublished Master's dissertation, Erasmus University, 2009 41-42.

11 Uromi (n 10 above) 327. Also see R Feragen The albino stage witness (2002) 445; United Nations General Assembly Report on Persons with Albinism, A/HRC/24/57, 12 September 20135.

12 LP Twohig \& V Kalitzkus Social studies of health, illness and diseases: Perspectives from the social sciences and humanities (2008) 115.

13 W Horobin (ed) Diseases and disorders (2008) 29; JE Richards \& RS Hawley The human genome: A user's guide (2010) 35; A Denniston \& PI Murray The Oxford handbook of ophthalmology (2009) 518; J Thomas \& P Kumar Clinical paediatric dermatology (2013) 114; BR Kutzbach et al 'Evaluation of vision-specific quality-oflife in albinism' (2009) 13 Journal of American Association for Paediatric Ophthalmology and Strabismus 191-195; CK Robert A dictionary of genetics (2006); M Neighbors \& J Tannel-Hill Human Diseases (2015) 458. Also see M Cummings Human heredity: Principles and issues (2009) 58-64; AH Robins Biological perspectives on human pigmentation (1991) 14; PJ Russell Fundamentals of genetics (2000) 186.

14 IOL 'Cops arrest trafficker, albino child still missing' http://www.iol.co.za/news/ crime-courts/cops-arrest-trafficker-albino-child-still-missing-2042005 (accessed 30 September 2016).

15 As above.

16 As above.

17 E-News 'Child living with albinism in KZN escapes death' http://www.enca.com/ life/kzn-traditional-healers-fighting-against-targeting-of-albinos 10 January 2016).

(accessed 
surrounding such crimes as well as the vulnerability of the targeted population. 18

In recent times, however, a number of attacks against persons with albinism have been reported in Africa. A July 2015 report compiled by Under the Same Sun (UTSS) Canada and Tanzania documented 148 killings of and 232 attacks on people with albinism across 25 African countries. The statistic for attacks includes survivors of mutilation; persons with albinism seeking asylum; incidents of violence against persons with albinism; and the desecration of graves. Of the 25 countries listed in the report, Tanzania is responsible for the majority of killings and attacks.

The mysterious abduction and killing of persons with albinism evoke feelings of uneasiness and insecurity in their communities ${ }^{19}$ and make them reluctant to walk, travel or stay alone because of the possible dangers. ${ }^{20}$ As a vulnerable minority group, persons with albinism are in need of social and legal protection in order to enjoy the full spectrum of fundamental rights, including the right to life and freedom of movement. The safety and security of persons with albinism require immediate attention before crimes against them spiral out of control. Having said that, it is clear that there is a case to be made for compelling the state, in particular, to intervene. Based on the Constitutional Court's groundbreaking decision in Carmichele $v$ Minister of Safety and Security, ${ }^{21}$ the article starts a debate on the duty on the state to prevent, investigate and punish violent acts against persons with albinism, as it is feared that the incidents reported in South Africa and elsewhere in Africa may trigger copycat crimes. Provisions from international and regional human rights instruments relevant to the issues faced by persons with albinism highlighted in the article are explored briefly.

\section{Need for protection by the state in situations of risk}

It is clear that the killing of persons with albinism has a range of negative repercussions and has established persons with albinism as a vulnerable group of people who are deserving of the same rights to safety and security as any other person. Vicious attacks and killings have significantly curtailed their freedom of movement as they hide in fear. Some learners with albinism have left school out of fear for their safety and those who do still attend school find it difficult to

18 United Nations Human Rights Council Advisory Committee Preliminary study on the situation of human rights of persons living with albinism A/HRC/AC/13/CRP.1 30 July 201415.

19 MM Masanja et al 'Albinism: Awareness, attitudes and level of albinos' predicament in Sukumaland, Tanzania' (2014) 3 Asian Journal of Applied Science and Engineering 1415.

20 Masanja et al (n 19 above) 15; Schühle (n 10 above) 15.

21 Carmichele v Minister of Safety and Security 2001 (4) SA 938 (CC). 
concentrate on their studies. Although this remains speculation, ${ }^{22}$ it is very likely that some of the children with albinism who vanished without a trace have been victims of muti murders, given the number of such murders reported across African countries. The brutal killing of Thandazile Mpunzi in KwaZulu-Natal in 2015, similarly, is cause for great concern.

Violent acts resulting in death or grave physical harm encroach upon a person's right to life and physical integrity. ${ }^{23}$ The Constitution, in section $12(1)(c)$, specifically protects the right to be free from all forms of violence 'from either public or private sources'. ${ }^{24}$ Further protection is found in section $12(1)(d), 25$ which addresses the right not to be tortured in any way, while section 12(1)(e) provides for the right not to be treated or punished 'in a cruel, inhuman or degrading way'. 26

The nature of the killing of persons with albinism is brutal. Knives and machetes are reportedly the objects used to cut limbs, breasts and other body parts off the helpless screaming victims. ${ }^{27}$ In the gruesome murder of Mpunzi mentioned previously, the victim was mutilated and skinned. There clearly is no room for the age-old concept of humanness, ubuntu, 28 in such violent behaviour. These brutal murders fail to honour the fundamental ubuntu values of life and human dignity. It is self-evident that there is no dignity in dying in this way.

Within the South African context, there has been very limited debate on the state's obligation to protect persons with albinism from violence. In the interests of identifying the most effective way of preventing these violent acts, what follows is an explanation of why the author supports the way in which the Carmichele case deals with private violence with the intention of giving value to constitutional protection; particularly the protection of the right to life, dignity and freedom from violence.

22 PA Carstens 'The cultural defence in criminal law: South African perspectives' (2004) 37 De Jure 312 http://www.isrcl.org/Papers/Carstens.pdf (accessed 22 January 2017).

23 United Nations General Assembly (n 11 above) 7. Also see D Bruce 'Killing and the Constitution: Arrest and the use of lethal force' (2003) 19 South African Journal on Human Rights 430.

24 Sec 12(1)(c) Constitution of the Republic of South Africa, 1996.

25 Sec 12(1)(d) South African Constitution.

26 Sec 12(1)(e) of the South African Constitution reads as follows: 'Everyone has the right to freedom and security of the person, which includes the right not to be treated or punished in a cruel, inhuman or degrading way.'

27 S Larson 'Magic, mutilation, and murder: A case for granting asylum to Tanzanian nationals with albinism' (2011) 2 Pace International Law Review 15-16.

28 J le Roux 'The impact of the death penalty on criminality' http://www.isrcl.org/ Papers/LeRoux.pdf (accessed 22 January 2016). Le Roux defines ubuntu as a culture in which communality and the interdependence of the members of a community are emphasised. An outstanding feature of ubuntu is the value it puts on life and human dignity. The notion that the life of another person is at least as valuable as one's own is emphasised. 
The South African vision of a society founded on the recognition of human rights means that everyone is obliged to value the right to life and the right to dignity. ${ }^{29}$ In the landmark case of Makwanyane, 30 Langa J made reference to South Africa's dark history in which the value of life and human dignity were 'demeaned'. He blamed political, social and other factors for having created a climate of aggression which has resulted in a culture of 'retaliation and vengeance' ${ }^{31}$ In the process, the major loss was that of reverence for life and the intrinsic worth of every human being. ${ }^{32}$ By retaining a form of punishment which failed to hold the dignity of the person and the value of human life in high regard, the state played a part in this disintegration. ${ }^{33}$ Bearing in mind that the state directs society's actions, in South Africa's new constitutional dispensation the state is obliged to guide society to respect the law and to demand that the killings come to an end and that human life and dignity are honoured. ${ }^{34}$ By implication, the state must also say no to the infringement of a criminal's right to life and dignity. ${ }^{35}$

The state has a duty to respect, protect, promote and fulfil the rights contained in the Bill of Rights. ${ }^{36}$ In terms of the right to life, this translates into both negative and positive duties. 37 The negative dimension of the right to life entails the duty not to take someone's life. ${ }^{38}$ The right to life can be construed positively as placing a duty on the state to protect the lives of its citizens. ${ }^{39}$ This argument was advanced in the Makwanyane case as justification for the retention of the death penalty. ${ }^{40}$ The Attorney-General's argument that the deterrent and preventative effects of the death penalty are an example of the state's duty to protect the right to life was rejected by the court. 41

The right to life entails the protection of a person's life against possible attack. ${ }^{42}$ At the very least, the positive duty imposed on the state by the right to life means that it is obliged to protect its citizens

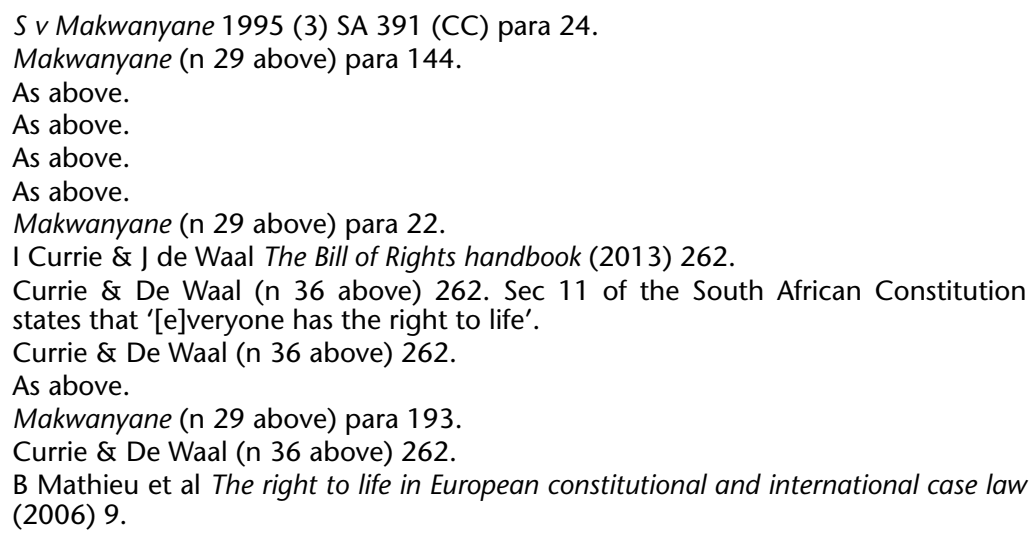


from 'life-threatening attacks' ${ }^{43}$ In the Carmichele case, ${ }^{44}$ this duty was emphasised in the context of the protection of the public by police officials and prosecutors.

The law dictates that under certain circumstances the state has a positive obligation to exercise due diligence, meaning that it ought to take all reasonable measures under the circumstances to prevent someone from infringing upon another's right to life in situations where they know or should know that such a risk exists. ${ }^{45}$ The obligation arises in cases where the state has a significant influence over the person committing the infringement or is under a duty of care with respect to the victim. ${ }^{46}$

In the Carmichele case, the Court further observed that ${ }^{47}$

[t]he police [are] one of the primary agencies of the state responsible for the protection of the public in general and women and children in particular against the invasion of their fundamental rights by perpetrators of violent crime,

thus suggesting that gender is of necessity a factor in determining wrongfulness. This observation has been interpreted as meaning that other pertinent factors may warrant the protection of certain other groups, given that the police have a broad duty to safeguard the most vulnerable members of society. ${ }^{48}$ In light of the increase in violent attacks against persons with albinism, the failure of the South African government to provide this vulnerable group with sufficient protection offers an analytical basis for imposing a duty upon the government to do so.

Grounded on a synthesis of the Constitutional Court's influential decision in the Carmichele case, such an affirmative duty entails the prevention, investigation and punishment by the state of violent acts against persons with albinism. Only by imposing this positive responsibility will persons with albinism be able to fully and freely exercise their rights and enjoy the new constitutional era.

In discussing the state's common law duty to protect human life, the Court in the Carmichele case adopted and embraced the positive dimensions in Osman $v$ United Kingdom: ${ }^{49}$

It is common ground that the state's obligation in this respect extends beyond its primary duty to secure the right to life by putting in place

43 Currie \& De Waal (n 36 above) 261.

44 Carmichele (n 21 above) paras 26, $28 \& 30$. Also see J Burchell Principles of criminal law (2013) 79-86.

45 Human Rights First 'Combating xenophobic violence: A framework for action' (2011) http://www.humanrightsfirst.org (accessed 10 February 2017).

46 As above.

47 Carmichele (n 21 above) para 62.

48 V Reddy et al 'Cloud over the rainbow nation: "Corrective rape" and other hate crimes against black lesbians' (2007) 5 Human Science Research Council Review 10 11.

49 Osman $v$ United Kingdom 29 EHHR 245 para 115. 
effective criminal law provisions to deter the commission of offences against the person backed up by law enforcement machinery for the prevention, suppression and sanctioning of breaches of such provisions. It is thus accepted by those appearing before the Court that article 2 of the Convention may also imply in certain well-defined circumstances a positive obligation on the authorities to take preventive operational measures to protect an individual whose life is at risk from the criminal acts of another individual.

The positive obligation of the state to prevent violations by non-state actors has developed as a standard of due diligence, a concept acknowledged in the law of torts. ${ }^{50}$ It is a duty of conduct, meaning that, if the state takes all reasonable measures within its authority to prevent the infringement of human rights, it will not be held accountable should such infringement nonetheless occur. ${ }^{51}$ Seen as a due diligence duty, prevention is the manifestation of protection. ${ }^{52}$ Due diligence demands such reasonable preventative measures as could be expected of governments under comparable circumstances. Perhaps the situation in some parts of Africa could be instructive in this regard, particularly in light of the fact that some African states have taken reasonable action to prevent violent attacks against persons with albinism. These will be used as examples in the course of this discussion.

In the case of the gravest violation of the rights of a person with albinism, namely, depriving them of their life and bodily integrity, it is worthless to offer subsequent compensation for something that cannot be reinstated. Although the protection in the Bill of Rights is relied upon to censure the conduct of perpetrators, litigation against perpetrators of violent acts against persons with albinism is likely to do little or nothing at all to address the misconceptions about albinism and attitudes towards people with the condition. On these grounds, it is argued that the state must take responsibility for protecting persons with albinism from violent crime and must ultimately be held answerable for its failure to act.

The litigation in the Carmichele case advances a strategy for bringing a protective suit against the state based on the contention that the state has a duty to protect persons with albinism from violent acts. In light of the rising statistics discussed earlier and the extreme likelihood that persons with albinism will be victims of a violent crime at some point in their lives, a group of persons with albinism could bring a suit and make a persuasive case that the court should not wait

50 DM Chirwa 'In search of philosophical justifications and suitable models for the horizontal application of human rights' (2008) 8 African Human Rights Law Journal 305. Also see DM Chirwa 'The doctrine of state responsibility as a potential means of making private actors accountable for human rights' (2004) 5 Melbourne Journal of International Law 13-14.

51 Chirwa (n 50 above) 305.

52 H Shue Basic rights: Subsistence, affluence, and US foreign policy (1980) 55; A Eide 'Economic, social and cultural rights as legal rights' in A Eide et al (eds) Economic, social cultural rights: A textbook (1995) 21 37. Also see Velásquez Rodríguez $v$ Honduras IACHR [1988] (Ser C) No 4. 
for a further case of victimisation before taking action. Although violent acts against persons with albinism generally are widespread, the recent consecutive incidents of abduction and murder of two children with albinism in KwaZulu-Natal clearly indicate that this region is a hotspot for violent crimes against persons with albinism, and point to a need for sustained security efforts in the area. All possible interim and preferably even long-term measures to halt this continued crime are urgently needed before the numbers spiral out of control.

Section 38 of the Constitution establishes comprehensive standing rights for those wishing to challenge the constitutionality of the state's action or inaction. Building on the Carmichele case with regard to the eligibility of vulnerable groups to approach the Constitutional Court to lodge a complaint about the violation of their rights which are enshrined in the Constitution, the author recommends that a suit be brought by a group of persons with albinism who are at risk of violent crime, or by other interested parties, or by albinism activists, to preventatively contest the constitutionality of the state's failure to protect persons with albinism. In its capacity as the highest court and supervisory body on constitutional compliance, the Constitutional Court has an obligation to act as the judicial arm of this vulnerable group of people and should exert pressure on the government of South Africa to make every effort to ensure their safety.

The state's duty to protect can entail (i) protection from violence; (ii) thorough investigation of incidents of violence; and (iii) mechanisms for holding violators accountable, including remedies for the victims. ${ }^{53}$

With reference once again to the concept of due diligence as necessitating such reasonable measures of prevention as could be expected from governments under comparable circumstances, this discourse now turns to measures taken by Tanzania, specifically in terms of the prevention and investigation of violent crimes against persons with albinism.

As the country with the highest incidence of violence against persons with albinism in Africa, Tanzania has implemented successful mechanisms for dealing with such crimes. Existing security structures in communities have been strengthened, particularly in schools. A substantial number of children are known to be in shelters for children with albinism who have been displaced by attacks, and these centres are regularly inspected for any abuse of or discrimination against these children. Tanzania has also developed a national institutionalised mechanism for the protection and promotion of the rights of persons with albinism. Measures include ensuring that national human rights institutions effectively monitor the human rights position of people with albinism. Furthermore, the Tanzanian government has taken

53 RJ Cook 'States responsibility for violation of women's human rights' (1994) 7 Harvard Human Rights Journal 127. 
steps to deal with the root causes of attacks and discrimination against people with albinism, notably by proactively contesting the stigma, false perceptions and myths surrounding the condition through ongoing awareness-raising campaigns on the scientific truth about albinism. The state is tasked with conducting fact-finding investigations wherever there is evidence of grave and widespread incidents of violence and discrimination against persons with albinism. Over 225 unlicensed witchdoctors were arrested and held to account in a crackdown on the murder of persons with albinism, and in 2016 witchdoctors were banned in Tanzania. ${ }^{54}$ It is clear that the Tanzanian government has taken stringent measures to protect persons with albinism and these reportedly have been successful in reducing the incidence of killings. ${ }^{55}$

In assessing the possibility to use such measures in South Africa, it is important to reflect on the lessons from the Carmichele case. Subsequent to Carmichele, the threat of a potential suit led to improvements in police investigations of violence against women; a victory in terms of imposing an obligation on the police to protect women from violence. ${ }^{56}$ A preventive suit affirming the state's failure to do enough to prevent violent crimes against persons with albinism, as well as the threat of possible subsequent suits, could perhaps have a comparable result, predominantly in terms of compelling the state to take action to transform the attitudes and deficiencies in policing and safety infrastructure that allow for violent acts against persons with albinism.

In South Africa, there is little systematic evidence of a state response to the violence against persons with albinism. The author is aware of only one document compiled by the state in 2013, namely, the Ekurhuleni Declaration on the Rights of Persons with Albinism. ${ }^{5} 7$ On paper the declaration seems promising, but a follow-up on the progress made in implementing its provisions reveals that the state is still falling short of meeting its commitments.

Three of the declaration's important recommendations in terms of violent crime against persons with albinism are: ${ }^{58}$

(1) that systems be established for comprehensive data collection on human rights violations perpetrated against persons with albinism;

54 D Smith 'Tanzania bans witchdoctors in attempt to end albino killings' https:// www.theguardian.com/world/2015/jan/14/tanzania-bans-witchdoctors-attemptend-albino-killings (accessed 22 January 2017).

55 DH Salewi 'The killing of persons with albinism in Tanzania: A social-legal inquiry' unpublished LLM dissertation, University of Pretoria, 201137.

56 M Govender 'Domestic violence: Is South Africa meeting its obligations in terms of the women's convention' (2003) 19 South African Journal on Human Rights 675.

57 Department of Women, Children and People with Disabilities 'Ekurhuleni Declaration on the Rights of Persons with Albinism' 25-27 October 2013 http:// www.gov.za/ekurhuleni-declaration-rights-persons-albinism (accessed 8 March 2017).

58 Arts 15, $16 \& 17$ Ekurhuleni Declaration on the Rights of Persons with Albinism (n 57 above). 
(2) that legislation be developed to enforce punitive action against perpetrators of violence against persons with albinism; and

(3) that the South African Human Rights Commission launch an investigation into incidents of human rights violations against persons with albinism.

Between 2009 and 2016, I was unable to source any extensive public reporting by the South African Human Rights Commission on violence against persons with albinism, and to date there has been no change. This makes it difficult to determine the exact nature of the problem and to identify the type of measures that would be most effective in dealing with it. Although the state has announced that there is a need for the development of legislation to enforce action against perpetrators of violence against persons with albinism, an extensive literature search yielded no information on even the drafting, let alone implementation, of specific legislation or measures for its enforcement.

Given the perceptions and attitudes that give rise to violence against persons with albinism, unquestionably the major challenge for the state is to enlighten the public by demystifying the condition of albinism through raising awareness of the condition and ensuring compliance with the fundamental rights protection afforded by the Constitution and other existing human rights instruments.

\section{National and international human rights framework applicable to the killing of persons with albinism}

Section 39 of the South African Constitution states that a court, tribunal or forum must promote the values that underlie an open and democratic society based on human dignity, equality and freedom (subsection (a)), must consider international law (subsection (b)), and may consider foreign law (subsection (c)). ${ }^{59}$

Section 231(2) \& (3) of the Constitution states that an international agreement binds South Africa once the treaty has been approved by the National Assembly and the National Council of Provinces, except if it is self-executing or of a technical, administrative or executive nature. ${ }^{60}$ In addition, section 232 determines that customary international law is law in South Africa, unless it is inconsistent with

59 Sec 39 of the South African Constitution reads as follows: '(1) When interpreting the Bill of Rights, a court, tribunal or forum - (a) must promote the values that underlie an open and democratic society based on human dignity, equality and freedom; (b) must consider international law; and (c) may consider foreign law. (2) When interpreting any legislation, and when developing the common law or customary law, every court, tribunal or forum must promote the spirit, purport and objects of the Bill of Rights. (3) The Bill of Rights does not deny the existence of any other rights or freedoms that are recognised or conferred by common law, customary law or legislation, to the extent that they are consistent with the Bill.'

60 Sec 231 of the Constitution of 1996 reads as follows: '1 The negotiating and signing of all international agreements is the responsibility of the national 
the Constitution or legislation. ${ }^{61}$ Under section 233 of the Constitution, South African courts are obliged to prefer any reasonable interpretation of legislation that is consistent with international law over any alternative interpretation that is inconsistent with international law. ${ }^{62}$ Provisions contained in international and regional human rights instruments which are relevant to the issues faced by persons with albinism, as highlighted in the article, are briefly explored below.

In November 2007, South Africa ratified the United Nations Convention on the Rights of Persons with Disabilities (CRPD), ${ }^{63}$ which is the most recent significant international human rights instrument relating to disability. The Preamble and article 1 of the CRPD affirm the social dimension of disability by stating that the definition of disability ought to be based on the social aspect of attitudinal and physical barriers that prevent persons with disabilities from effectively contributing to society. ${ }^{64}$ The CRPD looks beyond the question of 'access to the physical environment' and tackles concerns of equality and the elimination of legal, social and attitudinal obstacles to the involvement of people with disabilities. ${ }^{65}$ This social approach to disability shifts the focus from individuals and their physical or mental deficits to the manner in which society embraces or rejects them. ${ }^{66}$ Instead of disability being seen as unavoidable, it is viewed as a product of unfavourable social arrangements that can be transformed or even eliminated. ${ }^{67}$

The CRPD accepts that impairment and the environment interact to produce the experience of disability when people with impairments

executive. 2 An international agreement binds the Republic only after it has been approved by resolution in both the National Assembly and the National Council of Provinces, unless it is an agreement referred to in subsection (3). 3 An international agreement of a technical, administrative or executive nature, or an agreement which does not require either ratification or accession, entered into by the national executive, binds the Republic without approval by the National Assembly and the National Council of Provinces, but must be tabled in the Assembly and the Council within a reasonable time. 4 Any international agreement becomes law in the Republic when it is enacted into law by national legislation; but a self-executing provision of an agreement that has been approved by Parliament is law in the Republic unless it is inconsistent with the Constitution or an Act of Parliament. 5 The Republic is bound by international agreements which were binding on the Republic when this Constitution took effect.'

61 Sec 232 of the Constitution reads as follows: 'Customary international law is law in the Republic unless it is inconsistent with the Constitution or an Act of Parliament.'

62 Sec 232 of the Constitution of 1996 reads as follows: 'When interpreting any legislation, every court must prefer any reasonable interpretation of the legislation that is consistent with international law over any alternative interpretation that is inconsistent with international law.'

63 Convention on the Rights of Persons with Disabilities (CRPD).

64 SA Scott 'New category of colour: Analyzing albinism under Title VII of the Americans with Disabilities Act' (1999) 2 Journal of Gender, Race and Justice 514.

65 Scott (n 64 above) 514.

66 T Shakespeare Disability rights and wrongs revisited (2014) 12.

67 Shakespeare (n 66 above) 12. 
cannot participate in society on an equal basis. This more inclusive understanding of disability offers a more realistic framework for addressing the disadvantages commonly suffered by persons living with albinism. Their lifelong physical impairment means that these persons are continuously required to navigate circumstances arising from their distinctiveness. The social model of dealing with disability advances disability rights by removing the obstructions created by society. ${ }^{68}$ Amongst others, the CRPD requires that state parties undertake to adopt immediate, effective and appropriate measures to combat stereotypes, prejudices and harmful practices relating to persons with disabilities. ${ }^{69}$ Signatories to the CRPD are mandated to observe the provisions of the Convention by using them to drive domestic law and policy reforms.

Violent acts against persons with albinism have deprived them of their right to security of the person as protected by article 9 of the International Covenant on Civil and Political Rights (ICCPR). ${ }^{70}$ Although article 9 is primarily concerned with issues of arrest and

68 P Hurpur 'Embracing the new disability rights paradigm: The importance of the Convention on the Rights of Persons with Disabilities' (2012) 27 Disability and Society 4-5.

69 Art 8(1) of the CRPD reads as follows: '1 States Parties undertake to adopt immediate, effective and appropriate measures: (a) to raise awareness throughout society, including at the family level, regarding persons with disabilities, and to foster respect for the rights and dignity of persons with disabilities; (b) to combat stereotypes, prejudices and harmful practices relating to persons with disabilities, including those based on sex and age, in all areas of life; (c) to promote awareness of the capabilities and contributions of persons with disabilities. 2 Measures to this end include: (a) initiating and maintaining effective public awareness campaigns designed: (i) to nurture receptiveness to the rights of persons with disabilities; (ii) to promote positive perceptions and greater social awareness towards persons with disabilities; (iii) to promote recognition of the skills, merits and abilities of persons with disabilities, and of their contributions to the workplace and the labour market; (b) fostering at all levels of the education system, including in all children from an early age, an attitude of respect for the rights of persons with disabilities; (c) encouraging all organs of the media to portray persons with disabilities in a manner consistent with the purpose of the present Convention; (d) promoting awareness-training programmes regarding persons with disabilities and the rights of persons with disabilities.'

70 Art 9 of the International Covenant on Civil and Political Rights (ICCPR) reads as follows: '1 Everyone has the right to liberty and security of person. No one shall be subjected to arbitrary arrest or detention. No one shall be deprived of his liberty except on such grounds and in accordance with such procedure as are established by law. 2 Anyone who is arrested shall be informed, at the time of arrest, of the reasons for his arrest and shall be promptly informed of any charges against him. 3 Anyone arrested or detained on a criminal charge shall be brought promptly before a judge or other officer authorized by law to exercise judicial power and shall be entitled to trial within a reasonable time or to release. It shall not be the general rule that persons awaiting trial shall be detained in custody, but release may be subject to guarantees to appear for trial, at any other stage of the judicial proceedings, and, should occasion arise, for execution of the judgment. 4 Anyone who is deprived of his liberty by arrest or detention shall be entitled to take proceedings before a court, in order that that court may decide without delay on the lawfulness of his detention and order his release if the detention is not lawful. 5 Anyone who has been the victim of unlawful arrest or detention shall have an enforceable right to compensation.' 
detention it also has relevance for the protection of persons with albinism. ${ }^{1 / 1}$ It is clear that these persons live in fear of their lives because of the ongoing killings, and may become housebound as they do not feel safe on the streets. ${ }^{72}$ Many parents of children with albinism do not allow their children to walk to school. ${ }^{73}$

The killing of persons with albinism constitutes an infringement of the right to life as embodied in article 6 of the ICCPR, ${ }^{74}$ which affords every human being 'the inherent right to life'.

Further, article 26 of the ICCPR protects everyone - and therefore also persons with albinism - from all forms of discrimination. Within the context of the article, it may be argued that persons with albinism are discriminated against by being singled out for muti murders. The relevance here of article 26 is that it imposes an obligation upon member states to put in place mechanisms to prohibit any form of discrimination. Such mechanisms must guarantee equal and effective protection against discrimination on the grounds of colour, social origin or health status.

In South Africa, the majority of victims of violence against persons with albinism are children, being the most fragile and vulnerable members of society. ${ }^{75}$ Violence leading to death is a gross violation of a child's right to life under article 6 of the Convention on the Rights of the Child (CRC). South Africa ratified the CRC on 16 June 1995. ${ }^{76}$ This provision obligates state parties to recognise children's inherent right to life. In addition, it obliges state parties to ensure the survival and optimal development of the child.

71 A Alum et al Hocus pocus, witchcraft, and murder: The plight of Tanzanian albinos (2009) 13.

72 Alum et al (n 71 above) 41.

73 As above.

74 Art 6 of the ICCPR reads as follows: ' 1 Every human being has the inherent right to life. This right shall be protected by law. No one shall be arbitrarily deprived of his life. 2 In countries which have not abolished the death penalty, sentence of death may be imposed only for the most serious crimes in accordance with the law in force at the time of the commission of the crime and not contrary to the provisions of the present Covenant and to the Convention on the Prevention and Punishment of the Crime of Genocide. This penalty can only be carried out pursuant to a final judgment rendered by a competent court. 3 When deprivation of life constitutes the crime of genocide, it is understood that nothing in this article shall authorize any State Party to the present Covenant to derogate in any way from any obligation assumed under the provisions of the Convention on the Prevention and Punishment of the Crime of Genocide. 4 Anyone sentenced to death shall have the right to seek pardon or commutation of the sentence. Amnesty, pardon or commutation of the sentence of death may be granted in all cases. 5 Sentence of death shall not be imposed for crimes committed by persons below eighteen years of age and shall not be carried out on pregnant women. 6 Nothing in this article shall be invoked to delay or to prevent the abolition of capital punishment by any State Party to the present Covenant.'

75 P Bukuluki 'Child sacrifice: Myth or reality' (2014) 41 International Letters of Social and Humanistic Sciences 2.

76 United Nations Human Rights Office of the High Commissioner 'Status of Ratification Interactive Dashboard' http://indicators.ohchr.org/ (accessed 5 March 2017). 
Violent acts against children with albinism further constitute a violation of their right to education. Children with albinism may be afraid of or prevented from attending school for fear of being killed, as has been reported in some parts of South Africa. ${ }^{77}$ The right to education is recognised in article 28 of the CRC. ${ }^{78}$ In response to its obligations under the CRC, the Tanzanian government has introduced special measures to protect children living with albinism in the form of police escorts to accompany them to school. ${ }^{79}$ Such efforts aimed at ending the violence against and murder of children living with albinism $^{80}$ suggest that the Tanzanian government is aware of its commitments in terms of the CRC. ${ }^{81}$ As far as could be determined, no similar initiative exists in South Africa; certainly not one initiated by the South African government.

South Africa ratified the African Charter on Human and Peoples' Rights (African Charter) on 9 July $1996 .{ }^{82}$ The African Charter guarantees the right to life under article 4 which reads as follows: 'Human beings are inviolable. Every human being shall be entitled to respect for his life and the integrity of his person. No one may be arbitrarily deprived of this right.' In regulating the right to life, unlike other international and regional instruments, the African Charter is not supported by protocols that prohibit the death penalty, ${ }^{83}$ but it does explicitly and strongly condemn the taking of any human life. The lives of persons living with albinism are also protected against arbitrary killing under the Charter. The African Charter does not

77 Alum et al (n 71 above) 42-44.

78 Art 28 of the Convention on the Rights of the Child (CRC) reads as follows: '1 States Parties recognize the right of the child to education, and with a view to achieving this right progressively and on the basis of equal opportunity, they shall, in particular: (a) make primary education compulsory and available free to all; (b) encourage the development of different forms of secondary education, including general and vocational education, make them available and accessible to every child, and take appropriate measures such as the introduction of free education and offering financial assistance in case of need; (c) make higher education accessible to all on the basis of capacity by every appropriate means; (d) make educational and vocational information and guidance available and accessible to all children; (e) take measures to encourage regular attendance at schools and the reduction of drop-out rates. 2 States Parties shall take all appropriate measures to ensure that school discipline is administered in a manner consistent with the child's human dignity and in conformity with the present Convention. 3 States Parties shall promote and encourage international cooperation in matters relating to education, in particular with a view to contributing to the elimination of ignorance and illiteracy throughout the world and facilitating access to scientific and technical knowledge and modern teaching methods. In this regard, particular account shall be taken of the needs of developing countries.'

79 Alum et al (n 71 above) 42-44.

80 As above.

81 As above.

82 African Commission on Human and Peoples' Rights 'Ratification Table: African Charter on Human and Peoples' Rights' http://www.achpr.org/instruments/achpr/ ratification/ (accessed 5 March 2017).

83 MD Evans \& R Murray (eds) The African Charter on Human and Peoples' Rights: The system in practice 1986-2006 (2008) 189. 
merely describe the right to life as the legal foundation of all other rights, but as a right that is linked to the moral, physical and spiritual existence of a human being. ${ }^{84}$

Similar to the CRC, the African Charter on the Rights and Welfare of the Child (African Children's Charter), ratified by South Africa on 7 January 2000, is a comprehensive document on the human rights of children and associated global principles and standards. ${ }^{85}$ The Children's Charter came about because the member states of the Organisation of African Unity (OAU), now the African Union (AU), alleged that the CRC overlooked vital socio-cultural and economic issues specific to Africa. ${ }^{86}$ The African Children's Charter acknowledges the child's distinctive and honoured position in African society, and that children require protection against abuse and must be granted special care. ${ }^{87}$ In August 2015, the African Committee of Experts on the Rights and Welfare of the Child (African Children's Committee) conducted an on-site visit to the temporary holding shelters for children with albinism in the Lake Zone of Tanzania with the purpose of investigating the situation of the children hosted there. ${ }^{88}$ The purpose of the investigation was to inspect the situation of children with albinism in the temporary holding shelters and also to assess the abuses and challenges faced by these children. ${ }^{89}$ The Children's Committee was also tasked with identifying the causes resulting in the violation of the rights of children with albinism as well as imploring different stakeholders to assist with improving the protection of children with albinism in Tanzania. 90

Subsequent to the on-site visit, the African Children's Committee compiled a report which noted that children in the temporary holding shelters are in an exceedingly vulnerable situation, which makes them easy targets for witchcraft. ${ }^{91}$ The Committee also noted that the attacks and killings of children with albinism are extensive and are

84 Evans \& Murray (n 83 above) 185.

85 United Nations Children's Emergency Fund 'The African Charter on the Rights and Welfare of the Child' http://www.unicef.org/esaro/children_youth_5930.html (accessed 10 October 2015).

86 O Ekundayo 'Does the African Charter on the Rights and Welfare of the Child (ACRWC) only underline and repeat the Convention on the Rights of the Child (CRC)'s provisions? Examining the similarities and the differences between the ACRWC and the CRC' (2015) 5 International Journal of Humanities and Social Sciences 143.

87 Ekundayo (n 86 above) 147. 'One of the reasons for having an African Children's Charter was the feeling that Africa had been underrepresented during the drafting process of the CRC (only Algeria, Morocco, Senegal and Egypt participated meaningfully in the drafting process). A second reason was the thinking that Africa needed to have a charter for children which reflected the specifics of the African context.'

88 African Committee of Experts on the Rights and Welfare of the Child Report on Investigative Mission on the Situation of Children with Albinism in Temporary Holding Shelters in Tanzania, March 20162.

89 Report (n 88 above) 2-3.

90 As above.

91 Report (n 88 above) 16-18. 
impeding on a wide range of human rights of the affected children. ${ }^{92}$ In spite of some efforts by the Tanzanian government to deal with the situation, the African Children's Committee noted that the Tanzanian government had principally failed to fulfil its obligation under the African Children's Charter and other international and regional laws to protect the rights of children with albinism. ${ }^{93}$ The Committee concluded that, even though the Tanzanian government had instituted these temporary holding centres to safeguard these children from violent attacks, the shelters no longer served their temporary purpose and were not serving the best interests of the children as they 'feature[d] more like detention centres than safe houses'. 94 The report also noted that such shelters were providing an appropriate escape strategy for parents who wanted to detach themselves from the obligation of caring for their children with albinism. ${ }^{95}$ The Committee recommended that strategies be devised to provide these children with a family setting in order to end the permanent nature of the temporary holding centres. ${ }^{96}$

African children are notoriously exposed to various forms of maltreatment and deprivation, such as economic and sexual abuse, gender discrimination within educational and health care systems and involvement in armed conflict. ${ }^{97}$ Additional child-related issues in Africa include child prostitution; early marriages; child-headed households; street children; and a range of difficulties associated with

92 As above.
93 As above.
94 As above.
95 As above.

96 As above.

97 The Preamble of the African Children's Charter reads as follows: 'The African member states of the Organization of African Unity, parties to the present Charter entitled "African Charter on the Rights and Welfare of the Child", Considering that the Charter of the Organization of African Unity recognised the paramountcy of human rights and the African Charter on Human and People's Rights proclaimed and agreed that everyone is entitled to all the rights and freedoms recognised and guaranteed therein, without distinction of any kind such as race, ethnic group, colour, sex, language, religion, political or any other opinion, national and social origin, fortune, birth or other status; Recalling [that] the Declaration on the Rights and Welfare of the African Child (AHG/ST 4 Rev. 1) adopted by the Assembly of Heads of State and Government of the Organization of African Unity, at its sixteenth ordinary session in Monrovia, Liberia, from 17 to 20 July 1979, recognised the need to take appropriate measures to promote and protect the rights and welfare of the African Child; Noting with concern that the situation of most African children remains critical due to the unique factors of their socioeconomic, cultural, traditional and developmental circumstances, natural disasters, armed conflicts, exploitation and hunger, and on account of the child's physical and mental immaturity he or she needs special safeguards and care; Recognising that the child occupies a unique and privileged position in the African society and that for the full and harmonious development of his personality, the child should grow up in a family environment in an atmosphere of happiness, love and understanding; Recognising that the child, due to the needs of his physical and mental development, requires particular care with regard to health, physical, 
migration and extreme poverty. ${ }^{98}$ The African Children's Charter is an important instrument for the protection of the rights of children with albinism as it emphasises the protection of children from violence, discrimination, ill-treatment and negative social and cultural practices, including all forms of exploitation or sexual abuse and the kidnapping of and trafficking in children.

The above discussion highlights the fact that a more focused framework for the protection of the rights of persons with albinism is required at international level. Every state has a duty to honour the instruments and treaties which it has ratified.

As a constitutional democracy with a progressive Bill of Rights and a history of inequality, violence and discrimination, South Africa should make a special effort to ensure that the life, dignity and equal worth of all citizens are respected and to make adherence to the treaties and covenants discussed above a priority, particularly in terms of advancing the rights of persons living with albinism.

\section{Conclusion}

The article highlights cultural beliefs, superstitions, myths and false perceptions about albinism as the backdrop against which the violation of the rights of persons with albinism can be understood. In

mental, moral and social development, and requires legal protection in conditions of freedom, dignity and security; Taking into consideration the virtues of their cultural heritage, historical background and the values of the African civilisation which should inspire and characterise their reflection on the concept of the rights and welfare of the child; Considering that the promotion and protection of the rights and welfare of the child also implies the performance of duties on the part of everyone; Reaffirming adherence to the principles of the rights and welfare of the child contained in the declarations, conventions and other instruments of the Organization of African Unity and of the United Nations and in particular the United Nations Convention on the Rights of the Child, and the OAU Heads of State and Government's Declaration on the Rights and Welfare of the African Child ...'

98 Preamble (n 97 above). Art 27 (on sexual exploitation) of the African Children's Charter reads as follows: ' 1 State parties to the present Charter shall undertake to protect the child from all forms of sexual exploitation and sexual abuse and shall in particular take measures to prevent: (a) the inducement, coercion or encouragement of a child to engage in any sexual activity; (b) the use of children in prostitution or other sexual practices; (c) the use of children in pornographic activities, performances and materials.' Art 21 (on protection against harmful social and cultural practices) reads as follows: ' 1 State parties to the present Charter shall take all appropriate measures to eliminate harmful social and cultural practices affecting the welfare, dignity, normal growth and development of the child and in particular: (a) those customs and practices prejudicial to the health or life of the child; and (b) those customs and practices discriminatory to the child on the grounds of sex or other status. 2 Child marriage and the betrothal of girls and boys shall be prohibited and effective action, including legislation, shall be taken to specify the minimum age of marriage to be 18 years and make registration of all marriages in an official registry compulsory.' 
light of the prevalence of the intentional killing of persons with albinism, the article focuses on the way in which the current legal framework and, in particular, provisions on the right to life, dignity and freedom and security of the person enshrined in the Constitution, protect persons with albinism against violent attacks. The article critically assesses the impact of the brutal killings of persons with albinism in a democratic regime such as South Africa, and highlights the fact that people with albinism must be protected against physical attacks since the state has a duty to protect the right to life.

Although international human rights instruments cannot substitute domestic laws, they serve as an operational complement to domestic laws. The increase in violent attacks faced by persons with albinism calls for such a multi-faceted response. The international human rights instruments discussed in the article afford a distinctive basis for addressing the violent attacks and killings of persons with albinism. The position of the state as prime guardian for protecting the international human rights of persons living with albinism was emphasised, and the article calls on government to fulfil its international commitments towards protecting the rights of persons with albinism.

It is recommended that the Minister of Safety and Security appoints a task team to develop a strategy for implementing safety measures for persons with albinism. This strategy should be designed to put effective prevention plans and programmes into action to stop the spread of violence and crime against persons with albinism.

There is also a need for the general public to become involved in the protection of persons with albinism, rather than relying solely on the police, non-governmental organisations and human rights associations. A joint effort on the part of all stakeholders is needed if effective solutions are to be found. In addition, awareness campaigns about the plight of persons with albinism alone are not sufficient. It is recommended that the public be encouraged to devise and implement community-oriented security and policing initiatives in areas where persons with albinism reside, not as a substitute for formal policing, but as a complementary and supporting strategy.

While strict prosecution and severe sentencing of perpetrators of violence against persons with albinism should act as a deterrent, the South African government must be more vigilant and community advocacy should be a priority. If not contained and effectively addressed within a specific jurisdiction, dangerous beliefs such as those associated with albinism can easily spill over.

The trafficking in body parts of persons with albinism needs close scrutiny, and care must be taken to ensure that the implementation of the new Prevention and Combating of Trafficking in Persons Act ${ }^{99}$ extends to cover the removal of body parts from persons with 
albinism. In particular, the cross-border trade in body parts at border posts should be stopped. 